\title{
Penilaian Status Gizi dan Pengetahuan Gizi Seimbang Anak Usia Sekolah Sebagai Bentuk Aktivasi Kegiatan UKS
}

\author{
Anugrah Novianti ${ }^{1}$, Tyas Putri Utami ${ }^{2}$ \\ ${ }^{1}$ Program Studi Gizi Universitas Esa Unggul \\ ${ }^{2}$ Program Studi Farmasi Universitas Esa Unggul \\ e-mail: anugrah.novianti@esaunggul.ac.id
}

\begin{abstract}
Abstrak
Permasalahan gizi anak usia sekolah di Indonesia menurut data Riskesdas 2018 adalah anak dengan kategori pendek/stunting mencapai $30,7 \%$, sementara yang gemuk $8 \%$ dan anemia $26 \%$. Permasalahan gizi pada anak sekolah inilah yang akan mempengaruhi kualitas sumber daya manusia di masa datang, dikarenakan anak merupakan generasi penerus bangsa. Sehingga pengabdian kepada masyarakat ini bertujuan untuk meningkatkan pengetahuan siswa tentang gizi seimbang dan penilaian status gizi serta dapat mengoptimalkan kembali fungsi UKS dan berfokus pada permasalahan gizi anak sekolah. Kegiatan pengabdian masyarakat ini dilakukan di SDN Kedoya Utara 01 Jakarta Barat dengan responden yaitu seluruh siswa sekolah dasar yang berjumlah 422 anak. Pengabdian masyarakat ini dilakukan dalam bentuk gabungan dari beberapa bentuk kegiatan, yaitu pengambilan data status gizi siswa, penilaian pengetahuan gizi seimbang serta edukasi gizi seimbang. Hasil penelitian ini menunjukkan bahwa sebagian besar siswa kelas 1-6 memiliki status gizi normal, namun terdapat $18,8 \%$ siswa kelas $1-3$ yang berstatus gizi obesitas dan $9,1 \%$ berstatus gizi kurang. Dilihat dari tingkat pengetahuan siswa kelas 4-6 rata-rata memiliki skor pengetahuan $\leq 50$ yang artinya memiliki tingkat pengetahuan yang kurang. Hasil dari pengabdian masyarakat ini pun menunjukkan distribusi tingkat kecukupan energi protein pada siswa kelas 4-6, dimana didapatkan bahwa 67,8\% dan $42,7 \%$ siswa memiliki tingkat kecukupan energi protein defisit ringan hingga berat, selain itu sebesar $54,9 \%$ dan $75,2 \%$ siswa memiliki tingkat kecukupan lemak dan karbohidrat dengan kategori defisit ringan hingga berat.
\end{abstract}

Kata kunci: Status Gizi, Anak Usia Sekolah, Gizi Seimbang

\begin{abstract}
Nutritional problems for school-age children in Indonesia according to Riskesdas 2018 data are children with the stunting category reaching $30.7 \%$, while those who are fat are $8 \%$ and anemia is $26 \%$. Nutritional problems in school children will affect the quality of human resources in the future, because children are the nation's next generation. So that this community service aims to increase students' knowledge about balanced nutrition and nutritional status assessment and to optimize the function of UKS and focus on nutritional problems for school children. This community service activity was carried out at SDN Kedoya Utara 01 West Jakarta with respondents, namely all elementary school students totaling 422 children. This community service is carried out in the form of a combination of several forms of activities, namely data collection on student nutritional status, assessment of balanced nutrition knowledge and balanced nutrition education. The results of this study indicate that most of the students in grades 1-6 have normal nutritional status, but $18.8 \%$ of students in grades 1-3 are obese and $9.1 \%$ are malnourished. Judging from the level of knowledge, grade 4-6 students have an average knowledge score of $\leq 50$ which means they have a less knowledge level. The results of this community service also showed the distribution of protein energy adequacy levels in grade 4-6 students, where it was found that $67.8 \%$ and $42.7 \%$ of students had a moderate to severe deficit protein energy sufficiency level, besides $54.9 \%$ and $75.2 \%$ of students had adequate levels of fat and carbohydrates with mild to severe deficits.
\end{abstract}

Keywords: balanced nutrition, nutritional status, school age children

\section{PENDAHULUAN}

Kualitas anak-anak Indonesia merupakan penentu kualitas Sumber Daya Manusia (SDM) di masa mendatang dan menjadi generasi penerus pembangunan negara serta investasi Indonesia menuju negara maju yang dapat diperhitungkan di tingkat global. Salah 
satu penentu negara ini memiliki investasi sumber daya manusia yang berkualitas adalah pertumbuhan dan perkembangan anak-anak Indonesia. Terbentuknya SDM yang berkualitas, yaitu sumber daya manusia yang sehat, cerdas, dan produktif ditentukan oleh beberapa faktor, salah satunya adalah terpenuhinya kebutuhan pangan yang bergizi dan tercapainya status gizi optimal. Pemenuhan zat-zat gizi pada anak sekolah harus diberikan secara tepat baik dari segi kualitas maupun kuantitas. Hal ini dikarenakan anak sekolah termasuk ke dalam salah satu golongan yang rawan akan masalah gizi. Kurangnya memperhatikan makanan yang dikonsumsi akan mempengaruhi status gizi mereka. Rendahnya status gizi anak sekolah akan mempengaruhi kualitas Sumber Daya Manusia (SDM) di masa mendatang padahal anak sekolah merupakan generasi penerus dan pembawa perubahan bagi bangsa dan negara di masa depan.

Masalah gizi anak sekolah di Indonesia menurut data Riskesdas 2018 adalah anak pendek/stunting mencapai $30,7 \%$, sementara yang gemuk $8 \%$, dan anemia sebesar $26 \%$. Tingginya prevalensi kegemukan pada anak sekolah dasar akan meningkatkan risiko gizi terjadinya penyakit kronis seperti penyakit jantung, diabetes tipe 2 , kanker, osteoarthritis dan gangguan psikologis yang meningkatkan risiko kesakitan. Gizi lebih mempengaruhi kesehatan fisik dan mental, kualitas hidup terkait dengan kesehatan, serta menghabiskan uang (Dixon, 2010). Sementara itu, gizi kurang mampu meningkatkan risiko penyakit infeksi, memperlambat pertumbuhan dan perkembangan serta menurunkan tingkat kecerdasan (Sjarif, 2004). Secara bersama-sama, baik gizi kurang maupun gizi lebih mampu menganggu proses pertumbuhan dan perkembangan anak, meningkatkan risiko penyakit serta meningkatkan pengeluaran untuk biaya rumah sakit.

Adapun berbagai faktor yang mempengaruhi gizi lebih antara lain faktor genetik, demografi, sosial ekonomi, rendahnya tingkat pengetahuan, lokasi tempat tinggal, gaya hidup, dan gizi. Sementara faktor yang mempengaruhi gizi kurang adalah sosial ekonomi, lokasi tempat tinggal, hygiene sanitasi dan tingkat pengetahuan yang rendah.

Usaha Kesehatan Sekolah (UKS) merupakan salah satu wadah utama untuk pendidikan kesehatan disekolah yang mempunyai sasaran utama yaitu seluruh warga sekolah yang terdiri dari anak didik, guru, dan petugas-petugas sekolah lainnya. Dengan berlakunya undang-undang Nomer 32 Tahun 2004, maka berbagai program pelaksanaan UKS di setiap daerah pada dasarnya diserahkan kepada Tim Pembina UKS di daerahnya masing-masing untuk menentukan prioritas programnya. Berdasarkan pengamatan Tim Pembina UKS Pusat, pelaksanaan UKS sampai saat ini masih kurang sesuai dengan yang diharapkan. (Ahmad Selvia, 2009:1). Berdasarkan pengamatan dan wawancara penulis dengan salah satu guru di SDN Kedoya Utara 01 ini menunjukkan bahwa kegiatan UKS masih belum berjalan dan UKS hanya dijadikan sebagai tempat singgah siswa yang merasa kurang sehat. Selain itu, UKS di SDN Kedoya Utara 01 ini juga belum memiliki agenda program rutin yang jelas. Minimnya sarana dan prasarana UKS di sekolah-sekolah dasar juga masih menjadi kendala tersendiri bagi guru maupun pembina UKS. Sementara itu anggaran operasional UKS sendiri belum tercantum dalam RAPBS sehingga operasional UKS masih bersifat insidental (Ahmad Selvia, 2009:1). Hal ini dapat menjadi penyebab mengapa kegiatan UKS di Sekolah Dasar belum dapat berjalan dengan baik. Berdasarkan hal tersbut kegiatan pengabdian kepada masyarakat ini bertujuan untuk mengaktifkan kembali fungsi UKS dan berfokus pada permasalahan gizi anak sekolah dengan cara meningkatkan pengetahuan siswa tentang gizi seimbang dan melakukan penilaian status gizi.

\section{BAHAN DAN METODE}

Kegiatan pengabdian masyarakat ini dilakukan di SDN Kedoya Utara 01 Jakarta Barat pada bulan Januari tahun 2020 sebelum masa Pandemi Covid-19. Penelitian ini menggunakan teknik total sampling dimana yang menjadi responden adalah seluruh siswa sekolah dasar yang berjumlah 422 anak yang terdiri dari 298 siswa kelas 1 sampai kelas 3 SD dan 124 siswa kelas 4 hingga 6 SD. Penilitian ini merupakan pengambilan data dasar 
untuk penelitian lanjutan yang berjudul "Inovasi Kegiatan Usaha Kesehatan Sekolah (UKS) melalui Program Pojok Gizi (POZI) dalam Upaya Perbaikan Masalah Gizi Anak Sekolah Dasar", yang hingga saat ini belum dapat terlaksana karena adanya pandemik Covid-19. Kegiatan pengabdian masyarakat ini ialah bentuk gabungan atas beberapa kegiatan yaitu terdiri dari pengambilan data status gizi siswa, data asupan gizi siswa dan penilaian pengetahuan gizi seimbang.

Teknik pengumpulan data dalam penelitian ini berdasarkan urutan prosedur yaitu pengukuran antropometri siswa yang terdiri dari berat badan menggunakan timbangan digital merk GEA dengan ketelitian $0,1 \mathrm{~kg}$, tinggi badan menggunakan microtoise dengan ketelitian 0,1 cm, dan penilaian status gizi menggunakan Indeks Massa Tubuh/Usia (IMT/U) berdasarkan pengkategorian status gizi menurut Peraturan Menteri Kesehatan Republik Indonesia Nomor 2 Tahun 2020 tentang Standar Antropometri Anak dengan kategori status gizi anak sebagai berikut :
a. Gizi Buruk
$: \leq-3 \mathrm{SD}$
b. Gizi Kurang
$:-3$ SD s/d -2 SD
c. Gizi Baik/ Normal
$:-2$ SD s/d +1 SD
d. Risiko Gizi Lebih
$:>+1 \mathrm{SD} s / \mathrm{d}+2 \mathrm{SD}$
e. Gizi Lebih
$:>+2 \mathrm{SD}$
f. Obesitas
$:>+3 \mathrm{SD}$

Penilaian pengetahuan gizi seimbang hanya dilakukan pada siswa kelas 4-6 SD, menggunakan instrumen kuesioner elektronik. Tingkat kecukupan asupan siswa juga didapatkan dengan teknik wawancara menggunakan asupan recall $2 \times 24$ jam. Data yang terkumpul dianalisis univariat menggunakan software SPSS.
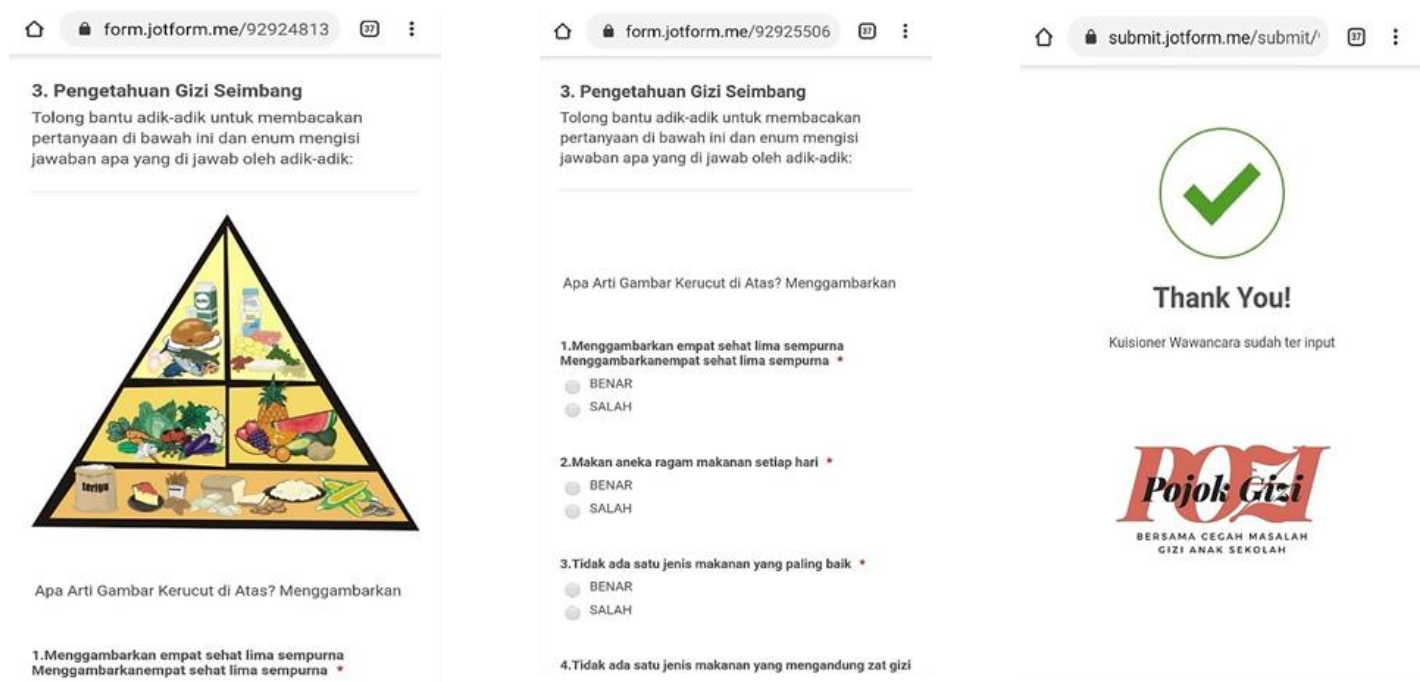

\section{Gambar 1. Contoh Tampilan Kuesioner Elektronik Pengetahuan Gizi Seimbang}

\section{HASIL}

Permasalahan gizi pada anak usia sekolah di Indonesia juga sering dikaitkan dengan tingkat pengetahuan gizi siswa yang kurang dan berhubungan dengan asupan gizi siswa. Penelitian ini menunjukkan bahwa status gizi siswa sebagian besar adalah dengan kategori Normal yaitu sebesar 59,7\% untuk siswa kelas 1-3 dan 64,5\% untuk siswa kelas 4-6. Selain itu, terdapat $18,8 \%$ siswa kelas $1-3$ dan $7,3 \%$ siswa kelas $4-6$ yang berstatus Gizi Lebih. Risiko Gizi Lebih dan status Gizi Lebih masih menjadi salah satu masalah gizi yang dialami siswa SDN Kedoya Utara 01 terlihat pada tabel 1. 
Tabel 1. Penilaian Status Gizi Siswa SDN Kedoya Utara 01

\begin{tabular}{lcccc}
\hline \multirow{2}{*}{ Kategori Status Gizi } & \multicolumn{2}{c}{ Kelas $\mathbf{1 - 3}$} & \multicolumn{2}{c}{ Kelas 4-6 } \\
\cline { 2 - 5 } & $\mathbf{n}$ & $\mathbf{\%}$ & $\mathbf{n}$ & $\mathbf{\%}$ \\
\hline Gizi Buruk & 4 & 1,3 & 2 & 1,6 \\
\hline Gizi Kurang & 24 & 8,1 & 16 & 12.9 \\
\hline Gizi Baik/ Normal & 178 & 59,7 & 80 & 64,5 \\
\hline Risiko Gizi Lebih & 36 & 12,1 & 17 & 13,7 \\
\hline Gizi Lebih & 56 & 18,8 & 9 & 7,3 \\
\hline Jumlah & $\mathbf{2 9 8}$ & $\mathbf{1 0 0}$ & $\mathbf{1 2 4}$ & $\mathbf{1 0 0}$ \\
\hline
\end{tabular}

Tabel 2.Penilaian Pengetahuan Gizi Seimbang Siswa Kelas 4-6 SDN Kedoya Utara 01

\begin{tabular}{cllll}
\hline \multirow{2}{*}{ Kategori Pengetahuan } & \multicolumn{2}{c}{ Kelas 4-6 } & & \\
\cline { 2 - 3 } & $\mathbf{n}$ & \% & Mean & Min-Max \\
\hline Kurang & 124 & 100 & 14,73 & $3-30$ \\
\hline Jumlah & $\mathbf{1 2 4}$ & $\mathbf{1 0 0}$ & & \\
\hline
\end{tabular}

Hasil analisis didapatkan bahwa seluruh siswa kelas 4-6 SDN Kedoya Utara 01 yang berjumlah 124 orang pada penelitian ini memiliki tingkat pengetahuan yang kurang digambarkan pada Tabel 2 dengan rata-rata skor nilai pengetahuan siswa ialah $\leq 50$ dan nilai tertinggi yang dicapai para siswa ialah 30 dari total nilai maksimum 100.

Tabel 3. Distribusi Frekuensi Tingkat Kecukupan Energi dan Protein Siswa Kelas 4-6

\begin{tabular}{cllll}
\hline \multirow{2}{*}{ Kategori Tingkat Kecukupan } & Energi & \multicolumn{3}{c}{ Protein } \\
\cline { 2 - 5 } & $\mathbf{n}$ & $\mathbf{\%}$ & $\mathbf{n}$ & $\mathbf{\%}$ \\
\hline Defisit Berat & 56 & 45,2 & 30 & 24,2 \\
\hline Defisit Sedang & 9 & 7,3 & 16 & 12,9 \\
\hline Defisit Ringan & 19 & 15,3 & 7 & 5,6 \\
\hline Cukup & 23 & 18,5 & 34 & 27,4 \\
\hline Lebih & 17 & 13,7 & 37 & 29,8 \\
\hline Jumlah & $\mathbf{1 2 4}$ & $\mathbf{1 0 0}$ & $\mathbf{1 2 4}$ & $\mathbf{1 0 0}$ \\
\hline
\end{tabular}

Tabel 3 menujukkan data distribusi frekuensi tingkat kecukupan energi dan protein siswa kelas 4-6 SD. Terdapat sebesar $67,8 \%$ dan 42,7\% siswa memiliki tingkat kecukupan energi dan protein defisit ringan hingga berat. Sedangkan terdapat sekitar 13,7\% dan 29,8\% siswa kelas 4-6 SD memiliki tingkat kecukupan energi dan proteinnya berlebih dari AKG (Angka Kecukupan Gizi).

Tabel 4.Distribusi Frekuensi Tingkat Kecukupan Lemak dan Karbohidrat Siswa Kelas 4-

\begin{tabular}{clllll}
\hline \multirow{2}{*}{$\begin{array}{c}\text { Kategori } \\
\text { Kecukupan }\end{array}$} & Tingkat & Lemak & \multicolumn{2}{c}{ Karbohidrat } \\
\cline { 2 - 5 } & & $\mathbf{n}$ & $\mathbf{\%}$ & $\mathbf{n}$ & $\mathbf{\%}$ \\
\hline Defisit Berat & 47 & 37,9 & 66 & 53,4 \\
\hline Defisit Sedang & 12 & 9,7 & 17 & 13,7 \\
\hline Defisit Ringan & 9 & 7,3 & 10 & 8,1 \\
\hline Cukup & 24 & 19,4 & 17 & 13,7 \\
\hline Lebih & 32 & 25,8 & 14 & 11,3 \\
\hline Jumlah & $\mathbf{1 2 4}$ & $\mathbf{1 0 0}$ & $\mathbf{1 2 4}$ & $\mathbf{1 0 0}$ \\
\hline
\end{tabular}


Tabel 4 menujukkan data distribusi frekuensi tingkat kecukupan lemak dan karbohidrat kelas 4-6 SD. Terdapat sebesar $54,9 \%$ dan $75,2 \%$ siswa memiliki tingkat kecukupan lemak dan karbohidrat defisit ringan hingga berat. Sedangkan terdapat sekitar 25,8\% dan 11,3\% siswa kelas 4-6 SD memiliki tingkat kecukupan lemak dan karbohidrat berlebih dari AKG (Angka Kecukupan Gizi). AKG lemak sesuai PMK 2019 untuk anak laki-laki usia 10-12 tahun yaitu 65 gram dan anak laki-laki usia 13-15 tahun ialah 80 gram, sedangkan anak perempuan usia 10-12 tahun ialah 65 gram dan usia 13-15 tahun ialah 70 gram. AKG karbohidrat sesuai PMK 2019 untuk anak laki-laki usia 10-12 tahun yaitu 300 gram dan anak laki-laki usia 13-15 tahun ialah 350 gram, sedangkan anak perempuan usia 10-12 tahun ialah 280 gram dan usia 13-15 tahun ialah 300 gram.

\section{PEMBAHASAN}

Dilihat dari hasil penilaian status gizi siswa dalam penelitian ini, sejalan dengan hasil data Riskesdas, tahun 2018 yang menyoroti permasalahan gizi triple burden malnutrition yang diderita anak Indonesia, yaitu masalah gizi kurus, obesitas dan defisiensi zat gizi mikro. Jika dilihat dari analisis asupan siswa kelas 4-6 SD, hal ini menunjukkan bahwa tingkat kecukupan energi dan protein yang sebagian besar siswa adalah defisit dari ringan hingga berat. Tingkat kecukupan energi dan protein yang defisit dapat berkontribusi pada status gizi kurang pada siswa. Tetapi perlu diketahui dimana hasil penilaian asupan pada siswa ini didapatkan dari wawancara dengan menggunakan kuesioner recall 2×24 jam yang pada saat observasi banyak ditemukan siswa yang lupa dan tidak fokus dengan pertanyaan juga ketika ditanyakan seputar porsi makanan yang dihabiskan. Hasil wawancara recall asupan siswa ini juga menunjukkan bahwa banyak siswa yang mengkonsumsi jenis makanan jajanan yang tidak mengandung sumber energi dan protein yang cukup untuk mencukupi kebutuhan gizi harian. Jenis makanan yang banyak dikonsumsi siswa tetapi tidak cukup mengandung sumber energi dan protein ialah snack ringan/ekstrudat, es atau minuman dingin, kue kering stik, permen, dan lain-lain.

\section{KESIMPULAN DAN SARAN}

Kegiatan pengabdian masyarakat ini sebagai upaya mengatasi permasalahan gizi anak usia sekolah dengan bentuk aktivasi UKS dan meningkatkan pengetahuan anak usia sekolah mengenai gizi seimbang. Peserta dalam kegiatan ini aktif dan bersemangat selama mengikuti kegiatan ini. Disarankan kepada dewan guru untuk tetap melaksanakan pemantauan status gizi anak minimal 1 bulan sekali, serta menyampaikan hasil penyuluhan kepada wali murid sehingga para wali murid dapat menjalankan prinsip gizi seimbang baik dirumah maupun di sekolah.

\section{UCAPAN TERIMA KASIH}

Terimakasih kepada Bapak Usman, S.Pd selaku Kepala Sekolah SDN Kedoya Utara 01 yang telah memberikan izin sehingga terlaksana nya kegiatan pengabdian ini. Terimakasih kepada Kepala Program Studi IImu Gizi Universitas Esa Unggul yang telah membantu terlaksananya program ini.

\section{DAFTAR PUSTAKA}

WHO Non-communicable Diseases Country Profiles 2014http://www.searo.who.int/indonesia/areas/noncommunicable disease/en/WHO, 2014. Global Status Report NCD 2014.

Anindita, N. (2014). Pengaruh penyuluhan gizi terhadap pengetahuan, konsumsi pangan, dan status gizi siswa obesitas di SMPN 5 Bogor (Skripsi tidak dipublikasikan). Institut Pertanian Bogor, Bogor, Indonesia. 
Ahmad Selvia .2009. Seri Pengetahuan UKS. Sidoarjo: Masmedia Buana Pustaka

Bappenas, BPS dan UNFPA. Proyeksi Penduduk Indonesia 2010-2035. Jakarta, 2013.

Februhartanthy, J. (2005). Nutrition education: It has never been an easy case for Indonesia.

Food and nutrition bulletin, 26(2), 267-274. Diakses dari https://www.ncbi.nlm.nih.gov/pubmed/16075577.

[Kemenkes] Kementerian Kesehatan. (2014). Peraturan Menteri Kesehatan Republik Indonesia Nomor 14 Tahun 2014 tentang pedoman gizi seimbang. Jakarta (ID): Direktorat Jendral Bina Gizi dan Kesehatan Ibu dan Anak.

[Kemenkes] Kementerian Kesehatan. (2018). Laporan hasil riset kesehatan nasional

2018. Jakarta (ID): Badan Penelitian dan Pengembangan Kesehatan. Kementerian Kesehatan RI.

[Kemenkes] Kementerian Kesehatan. (2001). Pedoman pelaksanaan pojok gizi (POZI) di Puskesmas Pedoman praktis tenaga gizi puskesmas. Jakarta: Direktorat Bina Gizi Masyarakat, Departemen Kesehatan RI. 